IRSH 65 (2020), pp. 67-92 doi:I0.1017/So020859020000I 40

(C) 2020 Internationaal Instituut voor Sociale Geschiedenis

\title{
The Expansion of Slavery in Benguela During the Nineteenth Century
}

\author{
MARIANAP. CANDIDO \\ Department of History, University of Notre Dame \\ 2 I9 O'Shaughnessy, Notre Dame, IN 46556 USA \\ E-mail: mcandido@nd.edu
}

\begin{abstract}
This article explores the nature and expansion of slavery in Benguela, in West Central Africa, during the nineteenth century, engaging with the scholarship on second slavery. Robert Palmer, Eric Hobsbawm, and Janet Polasky have framed the nineteenth century as the age of contagious liberty, yet, in Benguela, and elsewhere along the African coast, the institution of slavery expanded, in part to attend to the European and North American demand for natural resources. In the wake of the end of the slave trade, plantation slavery spread along the African coast to supply the growing demand in Europe and North America for cotton, sugar, and natural resources such as wax, ivory, rubber, and gum copal. In Portuguese territories in West Central Africa, slavery remained alive until I 869, when enslaved people were put into systems of apprenticeship very similar to labor regimes elsewhere in the Atlantic world. For the thousands of people who remained in captivity in Benguela, the nineteenth century continued to be a moment of oppression, forced labor, and extreme violence, not an age of abolition.

After the I 836 abolition of slave exports, local merchants and recently arrived immigrants from Portugal and Brazil set up plantations around Benguela making extensive use of unfree labor. In this article, I examine how abolition, colonialism, and economic exploitation were part of the same process in Benguela, which resulted in new zones of slavery responding to industrialization and market competition. Looking at individual cases, wherever possible, this study examines the kinds of activities enslaved people performed and the nature of slave labor. Moreover, it examines how free and enslaved people interacted and the differences that existed in terms of gender, analyzing the type of labor performed by enslaved men and women. And it questions the limitations of the "age of abolition".
\end{abstract}

\section{INTRODUCTION}

Urbanization and slavery have a long and intertwined history in West Central Africa and predate the early contact with Europeans in the late fifteenth century. Urban areas were located inland, away from the coast, yet they were important spaces of interaction and exchange, acting as political and economic 
centers. ${ }^{I}$ With the expansion of the Atlantic world, smaller settlements along the African coast became important commercial centers and new towns emerged, linked to internal markets and European cities and ports in the Americas. These new towns included the ports of Saint Louis and Gorée in Senegambia; Elmina and Anomabu along the Gold Coast; Cacheu on the Upper Guinea Coast; Ouidah, Porto Novo, and Lagos in the Bight of Benin; Bonny and Old Calabar in the Bight of Biafra; and Luanda, Cabinda, and Benguela in West Central Africa. ${ }^{2}$ The population of all these towns grew in the context of engagement with the Atlantic world and the expansion of the transatlantic slave trade. However, it is important to stress that urbanization in Africa predated the arrival of Europeans and the transatlantic slave trade, although further archeological research is necessary to provide more information on the nature and importance of West Central African urban centers.

In the era of Atlantic commerce, urban spaces on the African coast became centers of wealth concentration with the emergence of new commercial elites that profited from the sale of human beings along with ivory and gold. Several African ports had a sizable female population due to the pressures and dynamics of the slave trade but also the opportunities available in coastal towns. During the eighteenth century, population estimates indicate that women constituted the majority in coastal centers. For example, in the town of Cacheu on the Upper Guinea Coast there were $5 \mathrm{I} 4$ women and 386 men in $173 \mathrm{r}^{3}$ Luanda had 5,647 women and 4,108 men among its residents in

I. Jan Vansina, How Societies Are Born: Governance in West Central Africa before I600 (Charlottesville, VA, 2004); John K. Thornton, A Cultural History of the Atlantic World, I250I 820 (New York, 201 2).

2. Space does not permit me to list all sources that deal with urbanization along Western Africa and the transatlantic slave trade, but key among them are George E. Brooks, Landlords and Strangers: Ecology, Society, and Trade in Western Africa, I000-1630 (Boulder, CO, I993); Toby Green, "Building Slavery in the Atlantic World: Atlantic Connections and the Changing Institution of Slavery in Cabo Verde, Fifteenth-Sixteenth Centuries", Slavery \& Abolition, 32 (20I I), pp. 227-245; Filipa Ribeiro Da Silva, "Dutch Trade with Senegambia, Guinea, and Cape Verde, c.1590-1674", in Toby Green (ed.), Brokers of Change: Atlantic Commerce and Cultures in Precolonial Western Africa (Oxford, 2012), pp. I25-147; Lorelle Semley, To Be Free and French: Citizenship in France's Atlantic Empire, Critical Perspectives on Empire (Cambridge, 2017); Rebecca Shumway, "Castle Slaves of the Eighteenth-Century Gold Coast (Ghana)", Slavery \& Abolition, 35 (2014), pp. 84-98; Pernille Ipsen, Daughters of the Trade: Atlantic Slavers and Interracial Marriage on the Gold Coast, Early Modern Americas (Philadelphia, PA, 2015); Kristin Mann, Slavery and the Birth of an African City: Lagos, I760I900 (Bloomington, IN, 2010); Stacey Sommerdyk, "Rivalry on the Loango Coast: A Re-Examination of the Dutch in the Atlantic Slave Trade”, in Arlindo Manuel Caldeira (ed.), Trabalho Forçado Africano. O Caminho de Ida (Porto, 2009), pp. I05-I I8; Mariana P. Candido, An African Slaving Port and the Atlantic World: Benguela and Its Hinterland (New York, 2013). 3. Havik, Silences and Soundbites, Table 2, "Population Census I73 I". 
I78r. ${ }^{4}$ There were I,352 women and 892 men in Benguela in 1797.5 More information is available for port towns in the nineteenth century, as for the towns of Ouidah and Accra where women comprised the majority of the population. ${ }^{6}$ Free and enslaved women played important economic roles in these coastal centers as traders, farmers, shopkeepers, and nurses, among other activities. ${ }^{7}$ Similar to urban centers elsewhere along the Atlantic basin, slavery was central to the organization of the space and production of goods that attended populations in transit. ${ }^{8}$ Unlike other ports on the African coast, in West Central Africa the expansion of slavery was also intimately linked to the consolidation of the Portuguese colonial establishment in Luanda, Benguela, and inland fortresses. The construction of colonial infrastructure, including administrative centers, fortresses, and ports, relied on the exploitation of unfree labor, as I have discussed elsewhere. ${ }^{9}$

This study examines the expansion of slavery in Benguela during the nineteenth century. This period was a moment of profound transformation along the African coast, with the decline and abolition of slave exports as well as the expansion of slave labor in coastal and inland urban centers. Despite a historiography that celebrates the nineteenth century as the age of emancipation, liberty, and democratic revolutions, as framed by Robert Palmer, Eric Hobsbawm, and Janet Polasky, this study stresses the expansion and strengthening of the institution of slavery rather than its decline. ${ }^{1 \circ}$ The eighteenth- and

4. José C. Curto and Raymond R. Gervais, "The Population History of Luanda during the Late Atlantic Slave Trade, I78 I-I 844”, African Economic History, 29 (200I), pp. I-59, 55.

5. Arquivo Histórico Ultramarino (AHU), Angola, box 87, document 51, "Mapa das Pessoas Livres e escravos, empregos, e os oficios que varios tem", I January 1798. See Mariana P. Candido, Fronteras de esclavización. Esclavitud, comercio e identidad en Benguela, I780I850 (Mexico City, 201 I), pp. 76-99.

6. Law, Onidah, p. 76; John Parker, Making the Town: Ga State and Society in Early Colonial Accra (Portsmouth, NH, 2000), p. 190.

7. Claire C. Robertson, "We Must Overcome: Genealogy and Evolution of Female Slavery in West Africa”, Journal of West African History, i: ( 2015 ), pp. 59-92; Vanessa S. Oliveira, "Gender, Foodstuff Production and Trade in Late-Eighteenth Century Luanda", African Economic History, 43 (2015), pp. 57-8 I; Kristin Mann, "Women, Landed Property, and the Accumulation of Wealth in Early Colonial Lagos", Signs, I6 (I99i), pp. 682-706; Semley, To Be Free and French.

8. For other Atlantic ports see Mary C. Karasch, Slave Life in Rio de Janeiro, I808-1850 (Princeton, NJ, 1987); David Barry Gaspar and Darlene Clark Hine, More Than Chattel: Black Women and Slavery in the Americas (Bloomington, IN, 1996); Alejandro de la Fuente, Havana and the Atlantic in the Sixteenth Century (Chapel Hill, NC, 2008); Mann, Slavery and the Birth of an African City; Jane Landers, "Founding Mothers: Female Rebels in Colonial New Granada and Spanish Florida", Journal of African American History, 98 (2013), pp. 7-23.

9. See Candido, An African Slaving Port.

I0. For studies that celebrate the late eighteenth and early nineteenth century as the "Age of Revolution and Liberty" see Eric Hobsbawm, Age of Revolution 1789-I848 (London, 2010); Robert Roswell Palmer, The Age of the Democratic Revolution: The Challenge (Princeton, NJ, 1969); Janet L. Polasky, Revolutions without Borders: The Call to Liberty in the Atlantic World 
nineteenth-century liberal revolutions that swept the North Atlantic did not represent the end of African labor exploitation or even of slavery in West Central Africa. In fact, during the nineteenth century, slavery expanded in Luanda and Benguela as well as in other African urban centers, related to the transition to the so-called legitimate trade in natural resources such as ivory, and cash crops such as coffee, cocoa beans, and cotton. ${ }^{\mathrm{II}}$ Regaining, acquiring, or consolidating freedom became even more difficult for those who remained in bondage in West Central Africa. Individuals who petitioned for emancipation did not necessarily encounter supportive colonial officials or individuals who could help them in their quest for freedom. ${ }^{\mathrm{I} 2}$ In many ways,

(New Haven, CT, 20I5). The scholarship on the Portuguese empire, however, stresses that slavery not only continued to exist but also thrived during the nineteenth century. See, for example, João Pedro Marques, "Uma Cosmética Demorada. As Cortes Perante O Problema Da Escravidão (1 836-1875)", Análise Social, 36:1 58-I 59 (2001), pp. 209-247; Valentim Alexandre and Jill Dias, O Império Africano (Lisbon, 1998); Roquinaldo Ferreira, "Abolicionismo versus Colonialismo. Rupturas e Continuidades em Angola (Século XIX)”, in Roberto Guedes (ed.), África. Brasileiros e portugueses, séculos XVI-XIX (Rio de Janeiro, 20I3), pp. 95-II2; Vanessa S. Oliveira, "Trabalho escravo e ocupações urbanas em Luanda na segunda metade do século XIX", in Selma Pantoja and Estevam C. Thompson (eds), Em torno de Angola. Narrativas, identidades e conexões atlânticas (São Paulo, 2014), pp. 265-267.

I I. For more on this, see Paul E. Lovejoy and Jan S. Hogendorn, Slow Death for Slavery: The Course of Abolition in Northern Nigeria, I897-1936 (Cambridge, I993); W.G. Clarence-Smith, "Runaway Slaves and Social Bandits in Southern Angola, I875-1913", Slavery \& Abolition, 6:3 (1985), pp. 23-33; Sandra E. Greene, Slave Owners of West Africa: Decision Making in the Age of Abolition (Bloomington, IN, 2017); Trevor R. Getz, Slavery and Reform in West Africa: Toward Emancipation in Nineteenth-Century Senegal and the Gold Coast (Athens, OH, 2004); Samuël Cöghe, "The Problem of Freedom in a Mid-Nineteenth-Century Atlantic Slave Society: The Liberated Africans of the Anglo-Portuguese Mixed Commission in Luanda (I 844-1 870)", Slavery \& Abolition, 33 (2012), pp. 479-500; Jelmer Vos, "Work in Times of Slavery, Colonialism, and Civil War: Labor Relations in Angola from I 800 to 2000", History in Africa, 4I (20I4), pp. 363-385; Roquinaldo Amaral Ferreira, "Agricultural Enterprise and Unfree Labour in Nineteenth Century Angola", in Robin Law, Suzanne Schwarz, and Silke Strickrodt (eds), Commercial Agriculture, the Slave Trade and Slavery in Atlantic Africa (Woodbridge, 20I3), pp. 225-242; Suzanne Schwarz, "A Just and Honourable Commerce': Abolitionist Experimentation in Sierra Leone in the Late Eighteenth and Early Nineteenth Centuries", African Economic History, 45:I (2017), pp. I-45.

I2. See, for example, José C. Curto, "Un Butin Illégitime. Razzias d'esclaves et relations luso-africaines dans la région des fleuves Kwanza et Kwango en I805”, in Isabel de Castro Henriques and Louis Sala-Molins (eds), Déraison, Esclavage et Droit: Les fondements idéologiques et juridiques de la traite négrière et de l'esclavage (Paris, 2002), pp. 3 I 5-327; José C. Curto, "Struggling against Enslavement: The Case of José Manuel in Benguela, I816-20", Canadian Journal of African Studies, 39 (2005), pp. 96-122; José C. Curto, "Experiences of Enslavement in West Central Africa", Histoire Sociale/Social History, 4 I:82 (2008), pp. 38 I-4I 5; Roquinaldo Ferreira, "Slaving and Resistance to Slaving in West Central Africa", in David Eltis and Stanley L. Engerman (eds), The Cambridge World History of Slavery, vol. 3 (Cambridge, 20 I I), pp. I I I-I3I; Mariana P. Candido, "African Freedom Suits and Portuguese Vassal Status: Legal Mechanisms for Fighting Enslavement in Benguela, Angola, I800-1830”, Slavery E Abolition, 32 (20I I), pp. 447-459; Mariana P. Candido, "O limite tênue entre a liberdade e 
urban centers were not about opportunities and freedom but were threatening spaces. Several studies indicate that free Africans were kidnapped, enslaved, and deported to the Americas while conducting business, visiting friends or relatives, or transiting alone through coastal towns. ${ }^{13}$

The Portuguese empire abolished slave exports from West Central Africa in I 836, yet the use of local enslaved people expanded after this date. Local merchants and recently arrived immigrants from Portugal and Brazil set up plantations around Benguela, making extensive use of unfree labor. Cotton and sugarcane plantations were established in order to meet international demand for raw materials in the context of industrialization. In urban centers such as Benguela, enslaved labor use also expanded until slavery was abolished in I 869 , and a system of apprenticeship was put in place. ${ }^{14}$ This process of the "slow death" of slavery has received some scholarly attention for other locations in Africa, but not much has been written about this transition in West Central Africa. ${ }^{\text {Is }}$ While in recent decades Roquinaldo Ferreira, Samuël Cöghe, Jelmer Vos, and Vanessa S. Oliveira have published important studies

escravidão em Benguela durante a era do comércio transatlântico”, Afro-Ásia, 47 (2013), pp. 239-268.

I3. See Catarina Madeira Santos, "Esclavage africain et traite atlantique confrontés: transactions langagières et juridiques (à propos du tribunal de mucanos dans l'Angola des xviie et xviiie siècles)", Brésil(s). Sciences Humaines et Sociales, I (2012), pp. I27-I48; Mariana P. Candido, "The Transatlantic Slave Trade and the Vulnerability of Free Blacks in Benguela, Angola, I780I830", in Mark Meuwese and Jeffrey A. Fortin (eds), Atlantic Biographies: Individuals and Peoples in the Atlantic World (Leiden, 2013), pp. 193-210; Enrique Martino, "Panya: Economies of Deception and the Discontinuities of Indentured Labour Recruitment and the Slave Trade, Nigeria and Fernando Pó, I890s-1940s", African Economic History, 44 (2016), pp. 9I-I 29 .

I4. José de Almada, Apontamentos históricos sobre a escravatura e o trabalho indígena nas colónias portuguesas (Lisbon, I932), pp. 39-4I. For studies on the transformation of slavery into new forms of exploitation in West Central Africa, see Maria da Conceição Neto, "De escravos a serviçais, de serviçais a contratados. Omissões, percepções e equívocos na história do trabalho africano na Angola colonial", Cadernos de Estudos Africanos, 33 (2017), pp. 107-129; Aida Freudenthal, "Os quilombos de Angola no século XIX. A recusa da escravidão", Estudos Afro-Asiáticos, 32 (1997), pp. I09-I 34; Jelmer Vos, "Child Slaves and Freemen at the Spiritan Mission in Soyo, I880-1885", Journal of Family History, 35:1 (2010), pp. 71-90; Vos, "Work in Times of Slavery"; Ferreira, "Agricultural Enterprise".

1 5. For example, see Lovejoy, Slow Death for Slavery: The Course of Abolition in Northern Nigeria, I897-I936 (Cambridge, 1993); Martin A. Klein, Slavery and Colonial Rule in French West Africa (New York, 1998); Martin A. Klein, Alice Bellagamba, and Sandra E. Greene (eds), Bitter Legacy: African Slavery Past and Present (Princeton, NJ, 20I I); Frederick Cooper, From Slaves to Squatters: Plantation Labor and Agriculture in Zanzibar and Coastal Kenya, I890I925 (New Haven, CT, I980); Mohammed Bashir Salau, The West African Slave Plantation: A Case Study, Ist edn (New York, 201 I); Richard L. Roberts, Litigants and Housebolds: African Disputes and Colonial Courts in the French Soudan, I895-19I2 (Portsmouth, NH, 2005); Pamela Scully, Liberating the Family?: Gender and British Slave Emancipation in the Rural Western Cape, South Africa, I823-1853 (Portsmouth, NH, 1997); Elisabeth McMahon, Slavery and Emancipation in Islamic East Africa: From Honor to Respectability (New York, 2013). 
on the end of the slave trade and the expansion of unfree labor in commercial agriculture in Angola, much more research is needed, particularly regarding areas away from coastal centers and on the experiences of individuals in resisting forced labor. ${ }^{16}$ In addition to exploring the expansion of slavery, this study examines the activities enslaved people performed and the nature of slave labor and resistance in Benguela. By looking at individual cases it is possible to interrogate the differences that existed in terms of gender, analyzing the type of labor performed by enslaved men and women, and how slavery changed over time. Relying on primary sources from the Arquivo Nacional de Angola, the Tribunal da Comarca de Benguela (both in Angola), and the Arquivo Histórico Ultramarino (Portugal), this study discusses slavery in Benguela, helping us to analyze its meaning and limitations to the "age of liberty", and slavery's direct relationship with colonialism on the African coast. ${ }^{17}$

\section{BENGUELA AND THE AGE OF ABOLITION}

The nineteenth century was a period of profound transformations. ${ }^{18}$ Although the French, American, and Saint Domingue revolutions led to the reorganization of states, economies, and labor in different spaces, it was not a period of liberty everywhere and to everyone in the Atlantic world. ${ }^{19}$ The "universal cry of liberty" ${ }^{\circ}$ did not reach West Central Africa until the end of the nineteenth century, and it certainly did not endorse political emancipation for Africans. In the colony of Angola, which also included the administration of the town of Benguela and its interior, arguments about slave exporting and its consequences for the stagnation of local agricultural production occupied some of the debate between metropolis and colony in the early decades of the nineteenth century. Different colonial authorities reported that the growing slave trade in the early nineteenth century affected the consolidation of agricultural production and local industries. In 1805 , for example, the

ı6. Ferreira, "Agricultural Enterprise”; Cöghe, "Problem of Freedom”; Vos, "Work in Times of Slavery"; Paulo Teodoro de Matos and Jelmer Vos, "Demografia e relações de trabalho em Angola c. I800. Um ensaio metodológico”, Diálogos, I7:3 (2014), pp. 807-834; Roquinaldo Ferreira, “A supressão do tráfico de escravos em Angola (ca. I 830-ca. I 860)”, História Unisinos, I 5: I (20 I I), pp. 3-I3; Oliveira, "Trabalho escravo"; Vanessa S. Oliveira, Women and Slavery in Luanda (Madison, WI, forthcoming).

17. On the nineteenth century as the height of Enlightenment and freedom, see Hobsbawm, Age of Revolution; David Brion Davis, Slavery and Human Progress (New York, 1986).

I 8. Hobsbawm, Age of Revolution; Jeremy Adelman, Sovereignty and Revolution in the Iberian Atlantic (Princeton, NJ, 2006).

19. On contagious liberty see David Brion Davis, The Problem of Slavery in the Age of Revolution, I770-I823 (New York, 1999); Laurent Dubois, Avengers of the New World the Story of the Haitian Revolution (Cambridge, MA, 2004); Polasky, Revolutions without Borders, among others.

20. Polasky, Revolutions without Borders, p. 5. 
Catholic priest Boaventura José de Melo reported that the colonies of Benguela and Angola exported people who could produce food locally "due to the surplus of land and propitious environment". ${ }^{2 I}$ The governor of Angola in I 826, Nicolau Abreu Castelo Branco, personally encouraged the production of sugarcane to replace the export of captives, and recommended that the Portuguese Crown reward any trader engaged in new economic activities with an honorary induction into the Order of Christ. ${ }^{22}$ The Portuguese empire envisioned exploiting the production of cotton and indigo in addition to sugarcane, but also tapping into natural resources such as beeswax, gum copal, and orchil lichen - products in high demand from industries in Europe and North America. ${ }^{23}$ In all these industries coerced labor would respond to the demand for increased production.

Despite British pressure to bring the slave trade to an end and the progressive abolition of slavery in the Americas, there were protests that without enslavement it would be very difficult to maintain production since the local population was considered "unwilling to cooperate" and rebellious; it was claimed that the only way to obtain labor was through force and violence. ${ }^{24}$ The debates about colonialism, agricultural expansion, and new economic plans after the 1836 slave export ban continued into the 1840 s, despite the fact that the slave trade remained alive in part due to the demand in markets such as Cuba and Brazil. In I 844, José Joaquim Lopes de Lima, the colonial administrator in Goa and Timor, claimed "the infamous trade hurt our interest in Africa, stealing our hands who are employed in strange lands", making reference to the use of African enslaved labor in Brazil. ${ }^{25}$ Pamphlets and booklets were published to advance the idea that enslaved people should remain in West Central Africa to help consolidate Portuguese colonialism and agricultural production. ${ }^{26}$ Projects were approved to financially support agricultural expansion, relying, ironically, on the labor of enslaved people. For example, the Projeto de Regulamento da Companhia de Agricultura e Indústria de Angola e Benguela (Project to Regulate the Agriculture and Industry

21. AHU, Angola, box. I I 4, doc. 30, 23 November I 805 (old classification).

22. AHU, Angola, Codex 542, fol. I I Iv, 30 December I 826. New attempts were made in I 839 ; see Arquivo Nacional de Angola (ANA), Codex 221, fol. 17, 10 December I 839.

23. AHU, Angola, Codex 452, fol. I30v, 5 May I827; AHU, Angola, Correspondência dos Governadores, Folder 2, I 2 December I 836.

24. AHU, Angola, Correspondência dos Governadores, Folder 2 C, 30 September I 839; AHU, Angola, Correspondência dos Governadores, Folder I 8, I 5 December I 852.

25. Lopes de Lima cited in Roquinaldo Ferreira, "Escravidão e revoltas de escravos em Angola (I 830-1 860)", Afro-Ásia, 2 I-22 (1998), p. I4.

26. Joaquim Antonio de Carvalho e Menezes, Memoria geográfica, e política das possessões portuguezas n'Affrica occidental, que diz respeito aos reinos de Angola, Benguela, e suas dependências (Lisbon, I834), pp. 27-52; Arsênio P.P. de Carpo, Projecto de uma Companhia para o Melhoramento do Commércio, agricultura e indústria na Provincia de Angola (Lisbon, I 848$)$. 
Companies of Angola and Benguela) suggested shifting the focus from captive exports to a less lucrative though "noble" economic enterprise: the production of coffee, sugarcane, and natural resources within the Portuguese colonies in Africa. ${ }^{27}$ In many ways, the 1836 slave export ban led to the expansion of slavery locally, similar to what happened elsewhere in the Atlantic world, and leading to what historians have called the second slavery period. ${ }^{28}$ Plantations spread in Benguela and surrounding areas, such as Catumbela, Dombe Grande, and Cuio, as can be seen in Figure ${ }_{1} .^{29}$

In the I 850 , the newly appointed governor of Benguela, Vicente Ferrer Barruncho, was particularly interested in the development of a cash crop economy. In an I 856 report written a few months after his arrival in Benguela, he described the region of Dombe Grande as "excellent for agriculture. It could be even better if the heathens [gentio] were not so devoted to their customs and habits and neglectful of hard labor. [...] All the flour consumed in Benguela comes from this location". He observed that one example of prosperity was the Equimina farm, owned by Ignácio Teixeira Xavier, whom he described as an entrepreneur. In Equimina, Barruncho claimed, Teixeira Xavier

produced aguardente, but not sugar. [...] Labor was employed in the production of manioc, potato and maize. [...] I saw how the slaves are well employed and treated. Only 46 slaves were used, which included carpenters and a blacksmith. In the production of orchil lichen, 63 slaves are employed. In the coast town of Lucira, Teixeira Xavier employs 52 of his slaves in fishing. ${ }^{30}$

The governor suggested that Benguela residents should follow Teixeira Xavier's business model, employing enslaved and free labor for the advancement of plantation agriculture.

Barruncho's suggestions conformed with Portuguese colonial policies. With the end of transatlantic slave exports, the Portuguese administration encouraged the diversification of the economy, favoring the export of local staples such as orchil lichen. However, Barruncho's model entrepreneur, Teixeira

27. AHU, Angola, Correspondência dos Governadores, Folder 2, 8 April I 836.

28. Ada Ferrer, "Cuban Slavery and Atlantic Antislavery", Reviewe (Fernand Brandel Center), 3 I (2008), pp. 267-295; Dale Tomich and Michael Zeuske, "Introduction, the Second Slavery: Mass Slavery, World-Economy, and Comparative Microhistories”, Review (Fernand Braudel Center), 3 I (2008), pp. 9I-I00.

29. W.G. Clarence-Smith, The Third Portuguese Empire, I825-1975 (Manchester, I985); W.G. Clarence-Smith, Slaves, Peasants, and Capitalists in Southern Angola, 1840-1926 (Cambridge, 1979); Ai Freudenthal, Arimos e fazenda. A transição agrária em Angola, I850-I880 (Luanda: Chá de Caxinde, 2005); Oliveira, "Trabalho escravo".

30. Boletim Oficial do Governo Geral da Província de Angola (BOGGPA), no. 585 , I 3 December I 8 56, pp. 3-6, 26 November I 8 56. On the importance of orchil weed, see Maria Emília Madeira Santos (ed.), Viagens e Apontamentos de um Portuense em África. O Diário de Silva Porto (Coimbra, 1986), p. 75; Maria Cristina Cortez Wissenbach, “As feitorias de urzela e o tráfico de escravos. Georg Tams, José Ribeiro dos Santos e os negócios da África Centro-Ocidental na década de 1840”, Afro-Ásia, 43 (201 I), pp. 43-90. 


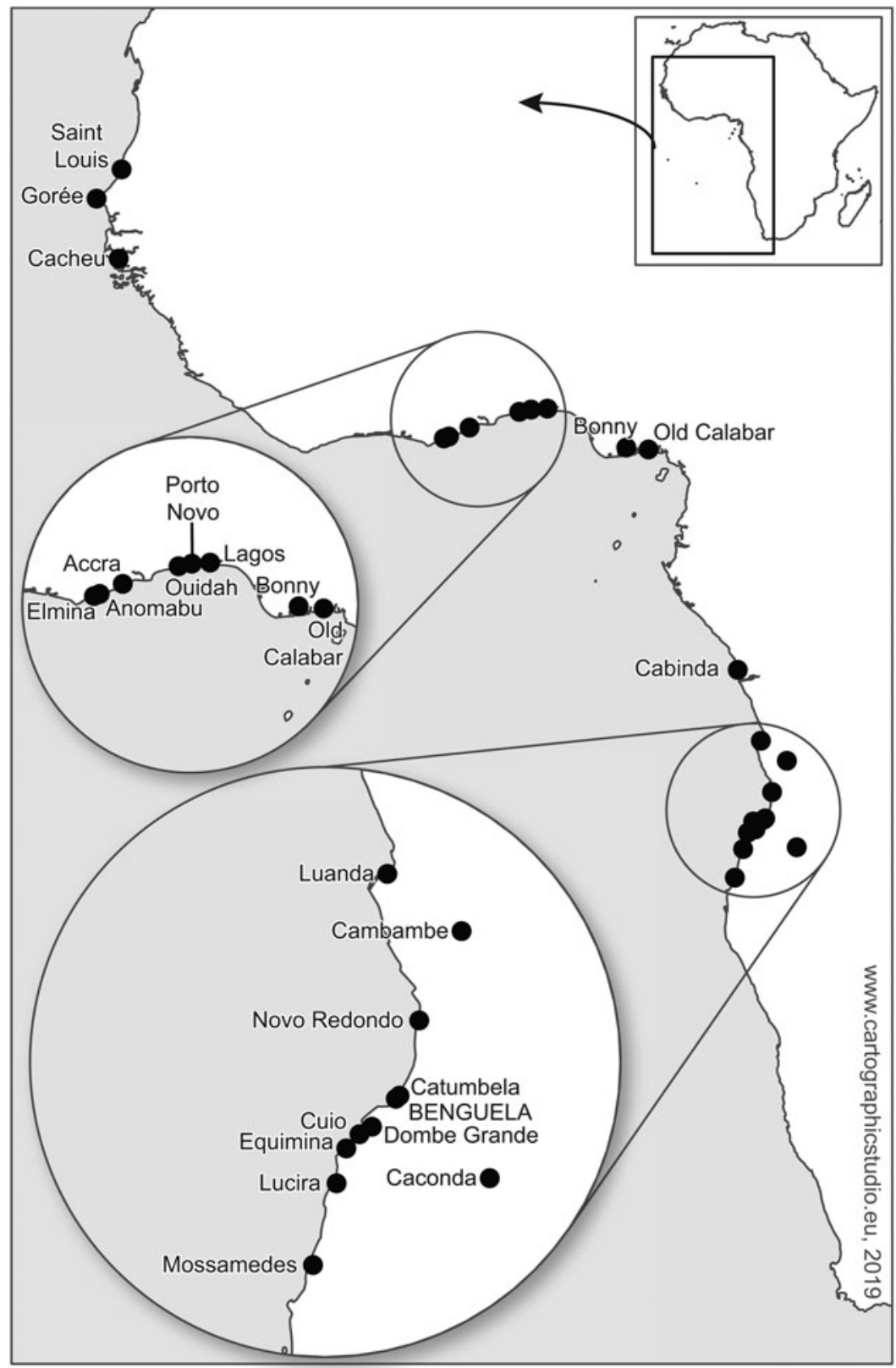

Figure I. The Western African coast, with details to locations mentioned in the text. 
Xavier, was later accused of smuggling enslaved labor overseas and using his plantations as a façade for his illegal business. This case shows how legitimate commerce in raw materials and tropical goods developed hand in hand with the smuggling of human beings. The governor of Angola, José Sobrinho Coelho do Amaral, accused Barruncho of involvement in the illegal slaving scheme, suggesting that Teixeira Xavier's legal activity camouflaged contraband trade in slaves. ${ }^{3 \mathrm{I}}$ The trader John Monteiro, who visited Benguela a few years later, argued that "only a very large number of cruisers on the Angolan coast could have prevented the shipment of slaves, as every man and woman, white or black, was interested in the trade, and a perfect system of communication existed from all points, overland and by sea". ${ }^{32}$ Thus, the expansion of agricultural production in Benguela and elsewhere in West Central Africa was connected to the growth of enslaved labor locally and contraband trade in human beings.

Slavery expanded in public and private spaces, including in official economic and household activities, and continued to exist as a legal institution until I 869 . However, individuals continued to be enslaved well into the I 870s. In I 873, for example, Bento Augusto Ribeiro Lopes seized two free women in Benguela and put them to work on his farm in Catumbela. ${ }^{33}$ Although the practice had been officially abolished, individuals like Ribeiro Lopes enslaved people without fear of any reprehension, a clear indication that the age of abolition had not reached West Central Africa, and Benguela in particular.

\section{THE ENSLAVED POPULATION}

Slavery was central to the economy of Benguela. Residents took part in the slave trade and profited from the auxiliary businesses. Enslaved labor was also vital to the organization of colonial urban space, and unfree people had represented a high proportion of the population of Benguela since its foundation in $1617 .{ }^{34}$ The collection of mapas populacionais, or population counts, since the end of the eighteenth century has made it possible to analyze the

3I. AHU, Angola, Correspondência dos Governadores, Folder 22A, doc. I 5 July i 856 ; see also BOGGPA, I865, no. 585 , I 3 December I 856, pp. 3-6. For more on this, see Freudenthal, Arimose Fazendas, 189-190; Alexandre and Dias, O Império Africano, pp. 398-402; Isabel de Castro Henriques, Percursos da Modernidade em Angola (Lisbon, 1997), pp. 532-550; Mariana P. Candido, "Trade, Slavery and Migration in the Interior of Benguela: The Case of the Caconda, I830-1870", in Beatrix Heintze and Achim von Oppen (eds), Angola on the Move: Transport Routes, Communications, and History (Frankfurt am Main, 2008), pp. 69-72.

32. Joachim John Monteiro, Angola and the River Congo (London, I876), p. 267.

33. ANA, box I322, Catumbela, is February i 873 .

34. Adriano Parreira, “A Primeira Conquista de Benguela”, História, Lisboa, I2:1 28 (I990), pp. 64-68; Aida Freudenthal, "Benguela. Da feitoria à cidade colonial”, Fontes E Estudos, 6-7 (201 I), pp. 197-229; Candido, An African Slaving Port. 
size of the free and unfree populations of Benguela. In 1798 , for example, there were $\mathrm{I}, \mathrm{I} 85$ enslaved people in Benguela out of a total population of 3,023 people (see Figure 2). In I 804, the first population account available for the nineteenth century indicates a decline in the overall population, with 889 free people and I,I I 8 enslaved people identified as living in Benguela. The higher proportion of enslaved individuals than free people continued until the end of the decade. In I 8 I I, the population count identified a surprisingly small free population of $35 \mathrm{I}$ individuals, compared to I,08 I enslaved people in the urban center. The population estimates do not include captives in transit, only those who resided in Benguela. These figures lead to questions about the violence and security necessary to control uprisings and flights. ${ }^{35}$

By I 8 I 3 , the ratio of free and unfree people was more balanced, as can be seen in Figure 2. By then, the free population was calculated at I,OI० people, while the unfree was $\mathrm{I}, \mathrm{I} 4 \mathrm{I}-$ a ratio of almost $\mathrm{I}$ : $\mathrm{I}$ that continued until I 826 . In the last population counts available prior to the 1836 slave export ban, 796 free and 74I enslaved people lived in Benguela.

Both free and enslaved populations declined in the 1833 population estimate, probably as a result of rearrangements in the slave trade, including the British ban on slave exports in 1808 , the ban north of the equator in I 814 , and the first attempt to bring slave imports to an end in Brazil in I $826 .^{36}$ Despite these efforts, people continued to be captured, enslaved, and exported from West Central Africa, and Benguela was no exception. However, the shifts in Atlantic commerce did affect the organization of the population of Benguela.

35. AHU, Angola, box 89, doc. 88. On Benguela household organization, see Instituto Histórico Geográfico Brasileiro (IHGB), DL $32,02.02$ and $\mathrm{DL}_{32,02.03}$. For a discussion on the slave population, see Candido, Fronteras de esclavización, pp. 9I-99. On the importance of population counts to West Central African history, see José C. Curto, "The Anatomy of a Demographic Explosion: Luanda, I844-1850", International Journal of African Historical Studies, 32:2-3 (1999), pp. 38 I405; Candido, "Trade, Slavery and Migration", pp. 63-84; Paulo Teodoro de Matos, "Population Censuses in the Portuguese Empire", Romanian Journal of Population Studies, I (2013), pp. 5-26; Matos and Vos, "Demografia e relações de trabalho"; Daniel B. Domingues da Silva, The Atlantic Slave Trade from West Central Africa, $1780-1867$ (Cambridge, 2017).

36. On the legislation related to the gradual abolition of the slave trade in the Portuguese empire, see Ferreira, "Supressão do tráfico de escravos"; Roquinaldo Ferreira, "Abolicionismo versus colonialismo. Rupturas e continuidades em Angola (século XIX)”, in Roberto Guedes (ed.), África. Brasileiros e Portugueses, séculos XVI-XIX (Rio de Janeiro, 20I3), pp. 95-II2; Roquinaldo Ferreira, "Measuring Short- and Long-Term Impacts of Abolitionism in the South Atlantic, I807-1860s", in David Richardson and Filipa Ribeiro da Silva (eds), Networks and Trans-Cultural Exchange: Slave Trading in the South Atlantic, I590-I867 (Leiden, 2014), pp. 22 I-237; Arlindo Manuel Caldeira, Escravos e traficantes no império português. O comércio negreiro português no Atlântico durante os séculos XV a XIX (Lisbon, 20I3); Domingues da Silva, Atlantic Slave Trade, pp. I6-37; Vanessa S. Oliveira, "Slavery and the Forgotten Women Slave Owners of Luanda (I846-I876)", in Paul E. Lovejoy and Vanessa S. Oliveira (eds), Slavery, Memory and Citizenship (Trenton, NJ, 2016), pp. I29-I47. 


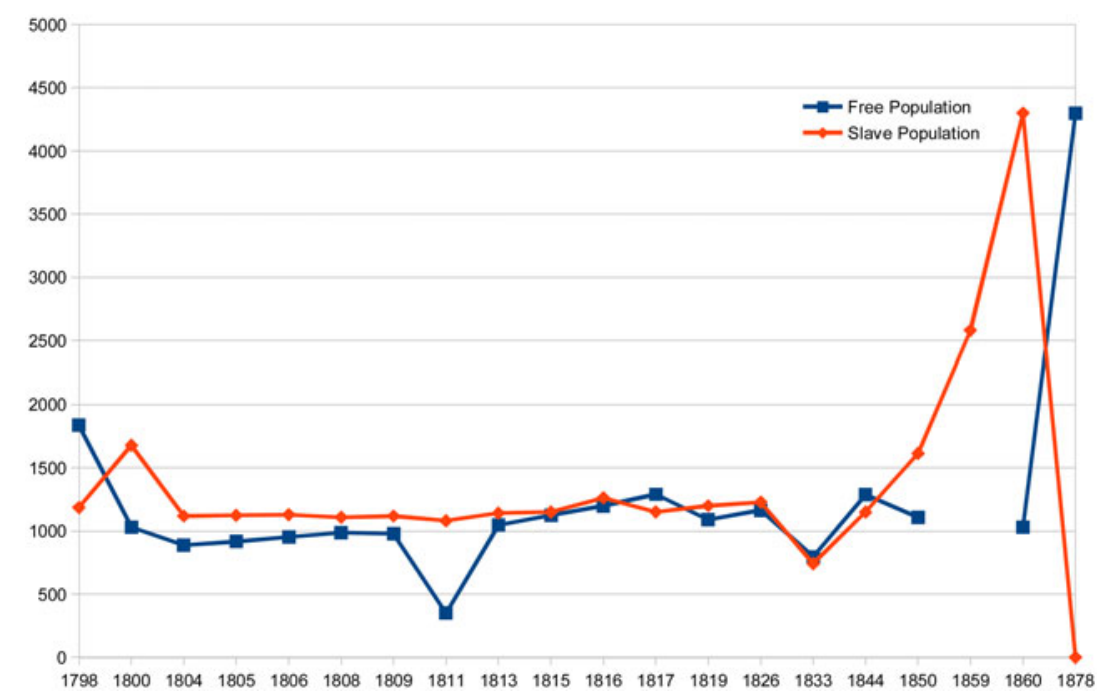

Figure 2. Benguela population by status, $1798-1833$.

Sources: AHU, Angola, I section, box 88, document 46; ANA, Codex 442, fols. I6Iv-I62; $A H U$, Angola, I section, box I13, document 6; AHU, Angola, I section, box I I6, document 87; AHU, Angola, I section, box II 8, document 2I; AHU, Angola, I section, box I20, document 21; AHU, Angola, I section, box I2 I, document 32; AHU, Angola, I section, box I24, document 8.; AHU, Angola, I section, box I27, document 59; AHU, Angola, I section, box 13 I, document 45; AHU, Angola, I section, box 133, document 32; AHU, Angola, I section, box 136, document 19; $A H U$, Angola, I section, box 138, document I; AHU, Angola, I section, box I56, document I6; AHU, Angola, I section, box I76, document 17 .

As can be seen in Figure 2, there was an increase in the number of enslaved people in Benguela after the 1836 ban. In I $844, \mathrm{I}, 288$ and I, I50 free and enslaved people lived in Benguela respectively. While there was a decline in the number of free people $(\mathrm{I}, \mathrm{I} 06)$, mainly fewer men, the unfree population jumped to I,6I4 people in I850, representing a ratio of I:I.5. The size of the slave population in 1859 is derived from the slave register rather than a specific population count, and thus the size of the free population is not certain, but it is important to remember that the end of slave imports in Brazil in I 850 provoked a major population reconfiguration in Luanda. ${ }^{37} \mathrm{~A}$ similar process seems to have occurred in Benguela, as suggested by the I 860 population count that shows I,029 free people and 4,298 enslaved people in the town. With the abolition of slavery in Portuguese possessions in 1869 , information about enslaved people was no longer collected in the population count.

37. On the population of Luanda, see Curto, "Anatomy of a Demographic Explosion"; Vanessa S. Oliveira, "The Donas of Luanda, c.1770-I867: From Atlantic Slave Trading to 'Legitimate' Commerce" (Ph.D., York University, 2016). 
After I 869, the category "slave" disappeared from the estimates, giving the illusion that all people who lived in territories under Portuguese control were free. This masks the fact that slavery remained alive under the name of contrato in the Portuguese empire well into the twentieth century. ${ }^{38} \mathrm{By}$ I 878 , the Benguela population count listed only free people, numbering 4,298 , creating the illusion that everyone enjoyed the same degree of freedom.

\section{THE INSTITUTION OF SLAVERY IN BENGUELA}

Since the 1960s, scholars have often discussed the nature of slavery in Africa, with some emphasizing how the institution differed from what developed in the Americas and elsewhere, in terms of skin-color classification, social stigma, and social insertion of slave descendants. ${ }^{39}$ Recent scholarship has emphasized the ways in which slavery continues to shape political and economic access to modern societies, and that slavery in Africa was much closer to slavery in the Americas than scholars were willing to recognize in the $19705 .^{40}$ There is no

38. Eric Allina, "Modern Slavery and Latter Day Pawns under Colonial Rule in Central Mozambique", in Joel Quirk and Darshan Vigneswaran (eds), Slavery, Migration and Contemporary Bondage in Africa (Trenton, NJ, 2013), pp. 37-63; Eric Allina, Slavery by Any Other Name: African Life under Company Rule in Colonial Mozambique (Charlottesville, VA, 20I2).

39. On the debate over the nature of slavery in Angola, see Isabel de Castro Henriques, Percursos da Modernidade em Angola. Dinâmicas comerciais e transformações sociais no século XIX (Lisbon: Instituto de Investigação Científica Tropical, 1997); W.G. Clarence-Smith, "Slavery in Coastal Southern Angola, I875-1913", Journal of Southern African Studies, 2 (1976), pp. 214-223; Joseph C. Miller, "The Paradoxes of Impoverishment in the Atlantic Zone", in David Birmingham and Phyllis Martin (eds), History of Central Africa, vol. I (London, 1983), pp. II 8-I 59; John Thornton, "The Slave Trade in Eighteenth Century Angola: Effects of Demographic Structure", Canadian Journal of African Studies, I4 (1980), pp. 417- 427. For the historiographical debate on the nature of slavery in Africa, see Suzanne Miers and Igor Kopytoff (eds), Slavery in Africa: Historical and Anthropological Perspectives (Madison, WI, 1977); Walter Rodney, History of the Upper Guinea Coast: 1545-I800 (New York: Monthly Review Press, 1980); Joseph C. Miller, "Imbangala Lineage Slavery", in Miers and Kopytoff, Slavery in Africa, pp. 205-233; Paul E. Lovejoy, Transformations in Slavery (New York, 2000); Suzanne Miers and Richard Roberts (eds), The End of Slavery in Africa (Madison, WI, 1988), pp. 3-58; Klein, Bellagamba, and Greene, Bitter Legacy, pp. I-I9; Daniel B. Domingues da Silva, "The Supply of Slaves from Luanda, I768-1806: Records of Anselmo Da Fonseca Coutinho", African Economic History, 38 (2009), pp. 53-76; Roquinaldo Ferreira, "Slavery and the Social and Cultural Landscape of Luanda", in Jorge Cañizares-Esguerra, Matt Childs, and James Sidbury (eds), The Black Urban Atlantic in the Age of the Slave Trade (Philadelphia, PA, 2013), pp. I $85-205$.

40. Green, "Building Slavery in the Atlantic World"; Chouki El Hamel, Black Morocco: A History of Slavery, Race, and Islam (New York, 20I3); Bruce S. Hall, A History of Race in Muslim West Africa, I600-1960, African Studies Series (Cambridge, 20I I); Jennifer Lofkrantz, "Idealism and Pragmatism: The Related Muslim West African Discourses on Identity, Captivity and Ransoming”, African Economic History, 42 (2015), pp. 87-107; Klein, Bellagamba, and Greene, Bitter 
doubt that the form of slavery that developed in Angola was shaped by local societies, but also by the fact that the territories were part of the Portuguese empire. In some respects, particularly notions of skin-color classification and emancipation, slavery in Angola had more in common with experiences in Brazil than elsewhere on the continent. During the nineteenth century, the apprenticeship regimes, notions of social mobility, and status and racial classification corresponded to what was happening in Brazil and in the Caribbean during the same period. ${ }^{4 \mathrm{I}}$ This also shows how ideas circulated in the Atlantic world, influencing how colonial officials perceived and operated within legal slave systems. ${ }^{42}$

Enslaved labor was essential to running the colonial center of Benguela. In I 800, for example, the Brazilian-born governor Félix Xavier Pinheiro de Lacerda owned four enslaved children employed as domestic servants. Also serving in his house were an enslaved man called Eusébio and a freed black man, José, who worked as a cook, showing that free and enslaved people worked side by side. ${ }^{43}$ In I8 I I, the governor of Benguela, António Rebello de Andrade Vasconcelos e Souza, had at least two young girls working as domestic slaves. ${ }^{44}$ In Benguela and in the interior, colonial authorities and

Legacy; Benedetta Rossi (ed.), Reconfiguring Slavery: West African Trajectories (Liverpool, 2009); Marie Rodet, "Escaping Slavery and Building Diasporic Communities in French Soudan and Senegal, ca. 1880-1940", International Journal of African Historical Studies, 48:2 (2015), pp. 363-386.

4I. See, for example, Hebe Maria Mattos de Castro, Das cores do silêncio. Os significados da liberdade no sudeste escravista: Brasil século XIX (Rio de Janeiro, I995); Beatriz G. Mamigonian, "In the Name of Freedom: Slave Trade Abolition, the Law and the Brazilian Branch of the African Emigration Scheme (Brazil-British West Indies, I $8305-18505)$ ), Slavery \& Abolition, 30 (2009), pp. 4I-66; Douglas Libby, "A Culture of Colors Representational Identities and Afro-Brazilians in Minas Gerais in the Eighteenth and Nineteenth Centuries", Luso-Brazilian Review, 50:I (2013), pp. 26-52; B.W. Higman, Plantation Jamaica, 1750-1850: Capital and Control in a Colonial Economy (Kingston, Jamaica, 2005); Rebecca J. Scott, Slave Emancipation in Cuba the Transition to Free Labor, I860-I 899 (Pittsburgh, PA, 2000).

42. On the circulation of colonial officers between Brazil and Angola and Benguela see Hebe Mattos, "Black Troops' and Hierarchies of Color in the Portuguese Atlantic World: The Case of Henrique Dias and His Black Regiment", Luso-Brazilian Review, 45:I (2008), pp. 6-29; Mariana P. Candido, "South Atlantic Exchanges: The Role of Brazilian-Born Agents in Benguela, I650-1850", Luso-Brazilian Review, 50:1 (2013), pp. 53-82; Roberto Guedes and Caroline S. Pontes, "Notícias do presídio de Caconda (1797). Moradores, escravatura, tutores e órfãos", in Eduardo França Paiva and Vanicléia Santos (eds), África e Brasil no Mundo Moderno (Belo Horizonte, 2013), pp. I53-180; Flávia Maria de Carvalho, Sobas e homens do rei. Relações de poder e escravidão em Angola (séculos XVII e XVIII) (Maceió, Alagoas, 2015).

43. Arquivo Nacional da Torre do Tombo (ANTT), Feitos Findos (FF), Justificações Ultramarinas (JU), África, bundle I 2, no. 9, 28 July I 800 . On the importance of slavery in Benguela, see Candido, An African Slaving Port; Roquinaldo Ferreira, "Biografia, mobilidade e Cultura Atlântica: A Micro-Escala do Tráfico de escravos em Benguela, séculos XVIII-XIX”, Tempo, 10:2 (2006); Freudenthal, "Benguela".

44. ANA, Codex 323, fol. 28-29, ig August I 8 I I; ANA, Codex 323, fol. 30-3 I, 20 August i 8 I I. 
residents employed enslaved people, both male and female, in house gardens, especially in the cultivation of maize, beans, manioc, and pumpkin to provide the town's food supply. ${ }^{45}$ Besides these domestic uses within household compounds, enslaved people were also employed as soldiers under Portuguese and African law. In the case of the Portuguese forces, officials employed enslaved males to march in front of the battalion; the military considered them dispensable soldiers. Despite their status as unfree persons, they carried weapons and were used to protect the free population who lived within the colonial centers as well as the long-distance trade caravans traveling inland. ${ }^{46}$

Before and after the 1836 slave export ban, enslaved people worked in mines in West Central Africa. In the interior of Angola, the Cambambe mines required a large number of workers, some of them with skilled training as blacksmiths. ${ }^{47}$ In Benguela, the most important mines were those that extracted sulfur as well as salt. These relied on laborers provided by local authorities, the sobas, who were forced to provide free and coercive labor to the colonial state as a tribute. While sulfur was mined for export, salt was shipped inland and utilized as currency to acquire products such as ivory or wax. ${ }^{48}$ Salt produced in the Benguela region was also exported to

45. IHGB, DL 32,02.0I "Relação dos moradores da cidade de São Filipe de Benguela", I 789 ; IHGB, DL8 I, 02.28, "Mapas feitos por Alexandre José Botelho de Vasconcelos, contendo censo das pessoas livres, escravos, casas, terras e senzalas", I796. For the use of enslaved people in farming in Bihé, see ANA, Codex 445, fol. 57-58, 2 I April I 8 I 0 . On the use of slave labor in gardens in Angola, see Selma Pantoja, "Donas de 'arimos'. Um negócio feminino no abastecimento de gêneros alimentícios em Luanda (séculos XVIII e XIX)", in Selma Pantoja (ed.), Entre Áfricas e Brasis (Brasilia, 200I), pp. 35-49; Mariana P. Candido, "Aguida Gonçalves da Silva, une dona à Benguela à fin du XVIIIe siècle”, Brésil(s). Sciences Humaines et Sociales, I (2012), pp. 33-54; Vanessa S. Oliveira, "Gender, Foodstuff Production and Trade in Late-Eighteenth Century Luanda", African Economic History, 43 (2015), pp. 57-8 I.

46. On the use of slaves in the military, see AHU, Angola, box 88, doc. 8, 10 June 1798. For some cases, see ANA, Codex 5 Io, fol. 9v, 20 May i 847; João Carlos Feo Cardoso de Castello Branco e Torres, Memórias Contendo a Biographia Do Vice-Almirante Luiz Da Motta Feo e Torres (Paris, I825), p. 344; Jean-Baptiste Douville, Voyage au Congo et dans l'interieus de l'Afrique Equinoxiale. Fait dans les années I828, 1829 et I830 (Paris, I832), vol. I, p. I8. See also Roquinaldo Ferreira, "O Brasil e a arte da guerra em Angola (sécs. XVII e XVIII)", Estudos Historicos, I:39 (2007), pp. 3-23; Sean Arnold Stilwell, Paradoxes of Power: The Kano "mamluks" and Male Royal Slavery in the Sokoto Caliphate, I804-1903 (Portsmouth, NH, 2004); Sparks, Where the Negroes Are Masters; Rudolph T. Ware, The Walking Qur'an Islamic Education, Embodied Knowledge, and History in West Africa (Chapel Hill, NC, 20I4); Jennifer Lofkrantz, "Protecting Freeborn Muslims: The Sokoto Caliphate's Attempts to Prevent Illegal Enslavement and Its Acceptance of the Strategy of Ransoming", Slavery \& Abolition, 32 (201 I), pp. I09-I 27; Paul E. Lovejoy, "Jihad and the Era of the Second Slavery", Journal of Global Slavery, I (2016), pp. 28-43.

47. Beatrix Heintze, Fontes para a bistória de Angola no século XVII, 2 vols (Stuttgart, 1985); Crislayne Alfagali, Ferreiros e fundidores da Ilamba. Uma história social da fabricação do ferro e da Real Fábrica de Nova Oeiras (Angola, segunda metade do século XVIII) (Luanda, 2018).

48. Thomas Edward Bowdich, An Account of the Discoveries of the Portuguese in the Interior of Angola and Mozambique (London, I824), p. 21; see also Almanak Statistico da Provincia de 
Luanda, where it supplied local needs in addition to vessels departing for the Americas. ${ }^{49}$

In a town where no animal transport existed, the colonial state employed enslaved people to convey all kinds of products and people. ${ }^{\circ}$ Groups of three or four enslaved men carried people in palanquins, unloaded the cargo from anchored ships, and carried both loads and passengers to the decks. ${ }^{5 \mathrm{I}}$ The movement of a passenger to or from a boat required the labor of four slaves to prevent the passenger from getting his or her clothes wet. ${ }^{22}$ Porters provided transportation inside the town and carried all sort of products, including toilet waste. ${ }^{53}$ Porters also carried the luggage of Portuguese administrators and ecclesiastical leaders who were moving to the interior. ${ }^{54}$ Enslaved men and women served as porters for the transportation of weapons, gunpowder, food, and military supplies for expeditions. ${ }^{5}$ In some cases, captives belonged to the administration, but Benguela residents were compelled to provide their own enslaved men, women, and children for colonial expeditions. ${ }^{56}$ These requisitions were not always popular. Masters wanted to avoid losing their labor and tried to get out of sending their captives, even by lying about their state of fitness. ${ }^{57}$

Angola, xix. On salt mines, see Antonio de Saldanha da Gama, Memória sobre as colonias de Portugal. Situadas na costa occidental d'Africa (Paris, I839), p. 7I; Miller, Way of Death, p. 56. On the labor extracted from local authorities, see Beatrix Heintze, "The Angolan Vassal Tributes of the 17th Century", Revista de História Económica e Social, 6 (1980), pp. 57-78; Carvalho, Sobas e homens do rei.

49. Miller, Way of Death, p. 274.

50. "Relatório do Governo de D. Miguel António de Mello," Boletim da Sociedade de Geografia de Lisboa, 5:9 (I885), p. 550.

5 I. On the use of slaves as palanquin carriers, see ANA, Codex 447, fol. $30 \mathrm{v}-34,6$ October I 8 I 8 ; ANA, Codex 507, fol. I29V-I32v, I 8 January I 8 I9. Carrying someone on a palanquin was an activity restricted to slaves throughout the South Atlantic world. See Miller, Way of Death, pp. I9I-192, 293; Karasch, "From Porterage to Proprietorship: African Occupations in Rio de Janeiro, I808-1850", in Race and Slavery in the Western Hemisphere: Quantitative Studies, ed. Stanley L. Engerman and Eugene D. Genovese (Princeton, N.J., 1975), pp. 377-379. On portage and prestige, see Magyar, Reisen in Süd-Afrika, ch. I, "Estadia em Benguela", p. 22; ch. 2, "Partida para o Interior de África”, p. I. On reactions to this practice, see Da Gama, Memória sobre as colonias de Portugal, p. 75 .

52. Feo Torres, Memórias Contendo a Biographia, p. 364 .

53. László Magyar, Reisen in Süd-Afrika in den Jabren I 849 bis I 857 (Leipzig, I859), ch. I, "Estadia em Benguela", p. 23. I would like to thank Conceição Neto for providing the Portuguese translation of the German edition of Magyar's diary.

54. See letters written by D. Miguel Antonio de Melo, governor of Angola, which stressed that internal journeys to Caconda could be costly; AHU, Angola, box IoI, doc. 3, 26 March I80I; AHU, Angola, box I 2 I A, doc. I6, 9 December I 8 ro; ANA, Codex 445, fol. I I Iv, i December I8I i; ANA, Codex 517, fol. 56v, 7 January 1796. See also Feo Torres, Memórias Contendo a Biographia, p. 303.

55. Douville, Voyage an Congo, vol. 2, p. i I7; A. J. R. Russell-Wood, The Black Man in Slavery and Freedom in Colonial Brazil (New York, 1982).

56. ANA, Codex 441, fol. 5, 27 July I796.

57. ANA, Codex 455 , fol. 267, I December I 846. 
The enslaved population also did most of the work in town as bakers, fishers, and tailors. Enslaved men and women employed in skilled positions enjoyed social status and some level of monetary compensation, which allowed them to save toward manumission. ${ }^{58}$ At the turn of the nineteenth century, António Pascoal was an enslaved blacksmith who belonged to Inés, a black woman. In I796, Pascoal acquired the support of Benguela's governor to establish a workshop in Benguela with his apprentice, António Felipe, thus becoming the only blacksmith in town. ${ }^{59}$ Fifteen years later, in I8II, Francisco, Dona Maria Domingos de Barros's slave, worked in the royal iron workshop and received a small sum of money for his work. ${ }^{60}$

Although enslaved people were everywhere in Benguela, the official correspondence provides little detail about the nature of their lives, their housing conditions, their family and religious experiences, or their daily lives (Figure 3).

\section{SLAVERY AFTER THE END OF SLAVE EXPORTS}

According to a report by the traveler Carlos José Caldeira, who visited Benguela in the late 1840 , the houses along the Morena beach served as gathering points for the ivory, wax, gum copal, leather, and orchil exported from the port. Caldeira reported that more than $\mathrm{I}, 000$ enslaved individuals were employed in the cultivation of orchil lichen at different plantations stretching from Benguela to the port of Mossamedes further south. ${ }^{6 \text { I }}$ The use of enslaved labor in major public construction projects such as the building of administrative houses or streets also continued after the slave export ban. To compensate for the physically demanding tasks and to avoid the possibility of escapes that would delay the progress of work, Portuguese agents offered compensation in the form of tobacco or alcohol to the enslaved men and women employed in urban infrastructure construction. ${ }^{62}$

In the I840s and I 850 , Benguela was a town in transition, moving away from slave exports and toward the use of enslaved labor locally, although smuggling continued to occur. Colonial authorities denounced attempts to embark captives illegally, in part because the continuing export of human

58. On cases of skilled slaves manumitted by slaveholders, see ANTT, FF, JU, África, bundle. 2, no. 3 A; ANTT, FF, JU, África, bundle 2, no. 3 B; ANTT, FF, JU, África, bundle. 2 I, no. I 2; ANTT, FF, JU, África, bundle. 22, no. 5. On cases in Luanda, see Oliveira, "Trabalho escravo". 59. ANA, Codex 442, fol. 2 I, 3 I October 1796.

60. ANA, Codex 445, fol. I23v, i February i 8 I 2.

6I. Carlos José Caldeira, Apontamentos d'uma viagem de Lisboa à China e da China a Lisboa (Lisbon, I 8 52), pp. 174-176. See also Monteiro, Angola and the River Congo, pp. 267-268. On the importance of wax in Benguela in the post-1850s, see Candido, "Trade, Slavery and Migration", p. 74.

62. ANA, Codex 453, fol. I sv, 24 November I 842. 


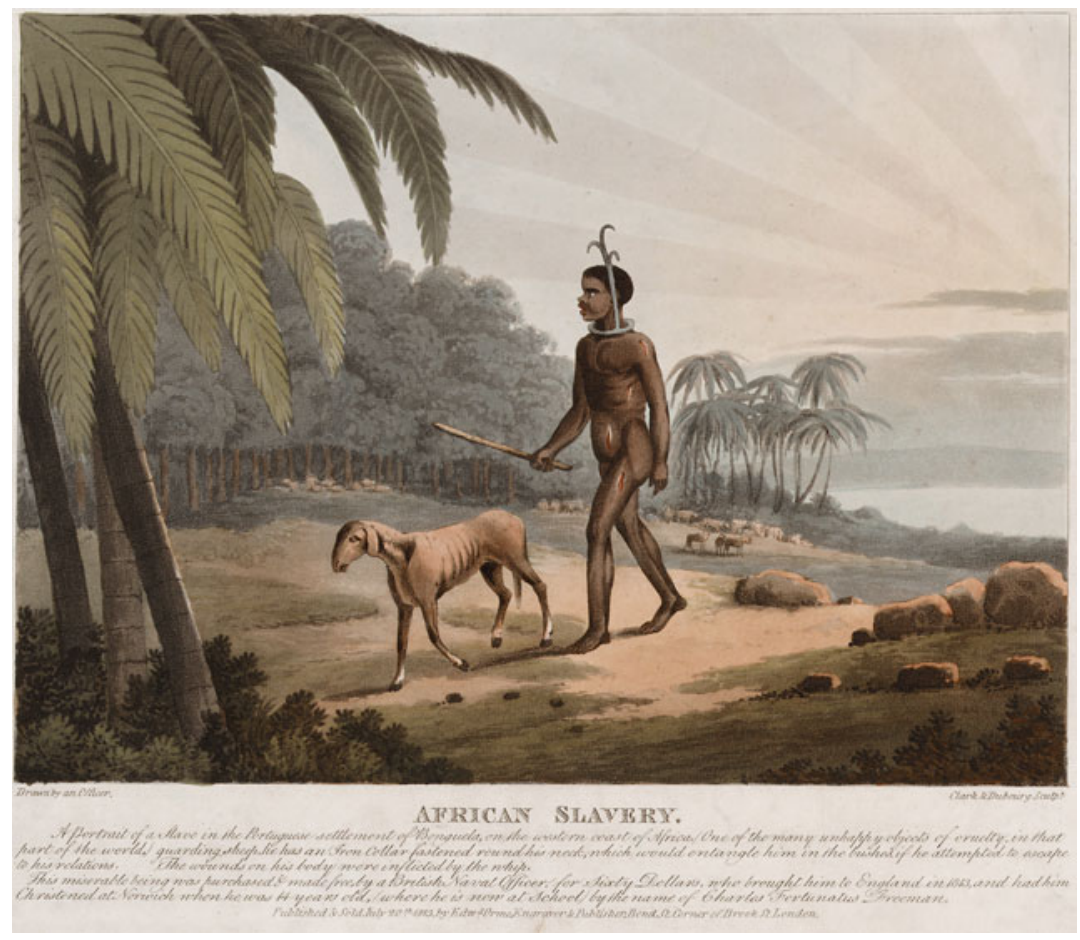

Figure 3. "A Portrait of a Slave in the Portuguese settlement of Benguela, on the western coast of Africa. (One of the many unhappy objects of cruelty, in that part of the world) guarding sheep, he has an Iron Collar fastened round his neck, which would entangle him in the bushes, if he attempted to escape to his relations. The wounds on his body were inflicted by the whip. This miserable being was purchased \& made free, by a British Naval Officer, for Sixty Dollars, who brought him to England in $\mathrm{I}_{8} \mathrm{I}_{3}$, and had him Christened at Norwich when he was I4 years old, where he is now at School by the name of Charles Fortunatus Freeman." Published by Edward Orme, Bond Street, London, July 20th i 8 I 3 .

National Maritime Museum, Greenwich, London, Michael Graham-Stewart Slavery Collection.

beings threatened the expansion of local agricultural enterprise. ${ }^{63}$ In I 854 , for example, I94 captives were located in Equimina, a beach south of Benguela, where slave traders planned to export them clandestinely. Among them were fifty-three men, thirty-three women, thirty-seven young girls, sixty-nine young boys, and five babies. The large number of children caught in this single operation underlines the large number of young people deported from West Central Africa in the nineteenth century. ${ }^{64}$ On the farms in Equimina, enslaved

63. AHU, 2 Section, Folder 30, 2 February 1862.

64. Tribunal da Comarca de Benguela (TCB), “Translado de uns autos de tomada e apreensão [...] José Luis da Silva Viana e Ignácio Teixeira Xavier, como abaixo se declara”, I 9 December I 8 54. For 
people, while secured with chains, iron collars, and shackles, produced, among other items, sugar and aguardente, a distilled sugarcane alcohol. ${ }^{65}$

In the I860s, the traveler John Monteiro described "the houses [of Benguela] having large walled gardens and enclosures for slaves". ${ }^{66}$ The visitors reported encountering enslaved people in the streets, in part due to the increase in the enslaved population in the wake of the 1836 slave export ban, the 1850 closure of the Brazilian market, and the local consolidation of the plantation economy, such as the establishment of large farms dedicated to the cultivation of sugarcane. ${ }^{67}$ The 1859 slave register provides some clues about the type of labor performed by unfree people. Male captives were listed with skilled positions including masons, fishermen, carpenters, cooks, and tailors. They also served as barbers, shoemakers, bakers, and sailors. ${ }^{68}$ There are few references to the occupations of enslaved women in the colonial documents, yet the slave register reveals that women also performed skilled labor as seamstresses, cooks, launderers, and street vendors. ${ }^{69}$ All of these urban activities benefited their masters, who profited from their street work. One of the main activities enslaved women performed in Benguela was to supply food and water to a population in constant movement. The concentration of many enslaved street vendors belonging to the same owner indicates that specific residents dominated some urban trade activities. António da Costa Covelo, a Benguela resident, owned thirty enslaved individuals, two-thirds of whom were women. While Covelo employed his male captives mainly in fishing and copper activities, eighteen out of his twenty enslaved women were street vendors. Covelo had only two female captives who were not quitandeiras: Sebastiana, an eight-year-old girl, and Joaquina, a one-year-old toddler. ${ }^{70}$

the literature on enslaved children in the nineteenth century, see David Eltis and Stanley L. Engerman, "Was the Slave Trade Dominated by Men?" Journal of Interdisciplinary History, 23 (1992), pp. 237-257; Audra Diptee, From Africa to Jamaica: The Making of an Atlantic Slave Society, I775-I807 (Gainsville, FL, 2012); Benjamin Nicholas Lawrance, Amistad's Orphans: An Atlantic Story of Children, Slavery, and Smuggling (New Haven, CT, 201 5 ).

65. ANA, Codex 475, fol. I, 7 November I865; Monteiro, Angola and the River Congo, p. 28I. This episode was also reported by the British Department of Foreign Affairs; see Lewis Hertslet, $A$ Collection of Treaties and Conventions, Between Great Britain and Foreign Powers, vol. X (London, I859), pp. 488-489.

66. Monteiro, Angola and the River Congo, p. 265.

67. W.G. Clarence-Smith, "Capitalist Penetration among the Nyaneka of Southern Angola, I 760 to I920s”, African Studies, 37 (1978); W.G. Clarence-Smith, Slaves, Peasants, and Capitalists in Southern Angola, I840-1926, African Studies Series 27 (Cambridge, 1979); Freudenthal, Arimos e fazendas; Freudenthal, "Benguela."

68. The Benguela slave register lists ninety fishermen, I 24 carpenters, fifty male cooks, and thirty tailors, among other occupations. See ANA, Codex 3160.

69. ANA, Codex $3160 ;$ Almanak statistico da Provincia d'Angola e suas dependencias para o anno de I852 (Luanda: Imprensa do Governo, I 85 I), p. 54.

70. ANA, Codex 3160. On enslaved women labor, see Robertson, "We Must Overcome"; Vanessa S. Oliveira, "Notas preliminares sobre punição de escravos em Luanda (século XIX)", 
At different times in the nineteenth century, women formed most of the enslaved population in Benguela, as can be seen in Figure 4. As in the pre-I 836 period, enslaved women worked on domestic tasks or in the house gardens, but also took part in urban commercial activities. ${ }^{7 \mathrm{I}}$ When employed in domestic tasks, enslaved women cleaned, took care of the house, and cooked; they also acted as nurses, performed many tasks in the house for the slave masters, and met their sexual demands. ${ }^{72}$

With the decline of slave exports and the expansion of legitimate commerce in ivory, beeswax, and then wild rubber, enslaved people were also put to work on the new farms and plantations established around Benguela and in Dombe Grande. There, they provided much of the labor needed for the cultivation of cotton and sugarcane, and for orchil lichen collection. ${ }^{73}$ The businesswoman Teresa de Jesus Barruncho established plantations in Benguela, Cuio, and Dombe Grande. By i86I, she had three different plantations in Dombe Grande; on one of her plantations she had more than 300 captives, many of them women. As a result, Barruncho became the leading exporter of cotton and wax from the port of Benguela. ${ }^{74}$

Reports indicate that, during the I860s, the landscape was transformed by the expansion of agriculture and the plantation economy as "the great plains that used to be covered by dense woods and served as refuge for wild animals, are now clear of trees, and almost all of the land along the coast is now plantations of cotton and sugarcane". ${ }^{75}$ By the second half of the nineteenth century, slavery in Benguela resembled the plantation economy in the Americas. While urban slavery continued to be important, many of Benguela's wealthy residents expanded their business activities in surrounding areas by investing in

in O colonialismo português. Novos rumos da historiografia dos PALOP (Porto, 2013), pp. I55I76; Oliveira, "Slavery and the Forgotten Women Slave Owners"; Oliveira, "Trabalho escravo". 71. See Selma Pantoja, "As Fontes Escritas do Século XVII e o Estudo da Representação do Feminino em Luanda", in Construindo o passado Angolano. As fontes e a sua interpretação. Actas do II Seminário internacional sobre a história de Angola (Lisbon, 2000), pp. 583-596.

72. Magyar, Reisen in Süd-Afrika, ch. I: "Estadia em Benguela”, p. Iо. I am very grateful to Maria da Conceição Neto, who shared her Portuguese translation of the original Hungarian. On the sexual exploitation of enslaved women in Benguela, see Mariana P. Candido, "Concubinage and Slavery in Benguela, c.1750-1850", in Olatunji Ojo and Nadine Hunt (eds), Slavery in Africa and the Caribbean: A History of Enslavement and Identity Since the I8th Century (London, 20I2), pp. 65-84.

73. AHU, Angola, Codex 542, fol. I i iv, 30 December i 826; Feo Torres, Memórias Contendo a Biographia, pp. 334-335; da Gama, Memória sobre as colônias de Portugal, p. 8; Almanak Statistico da Provincia de Angola, p. 50.

74. BOGGPA, I862, no. 894, 22 November I862, fol. 333-334; BOGGPA, i864, no. 6, 6 February I 864, fol. 55. See also Freudenthal, Arimos e Fazendas, p. 21 3 ; Alexandre and Dias, $O$ Império Africano, p. 450.

75. AHU, Correspondência dos Governadores, Folder 38, 21 December 1868, document

"Relatório do Governo de Benguela referente a s 864-68". 


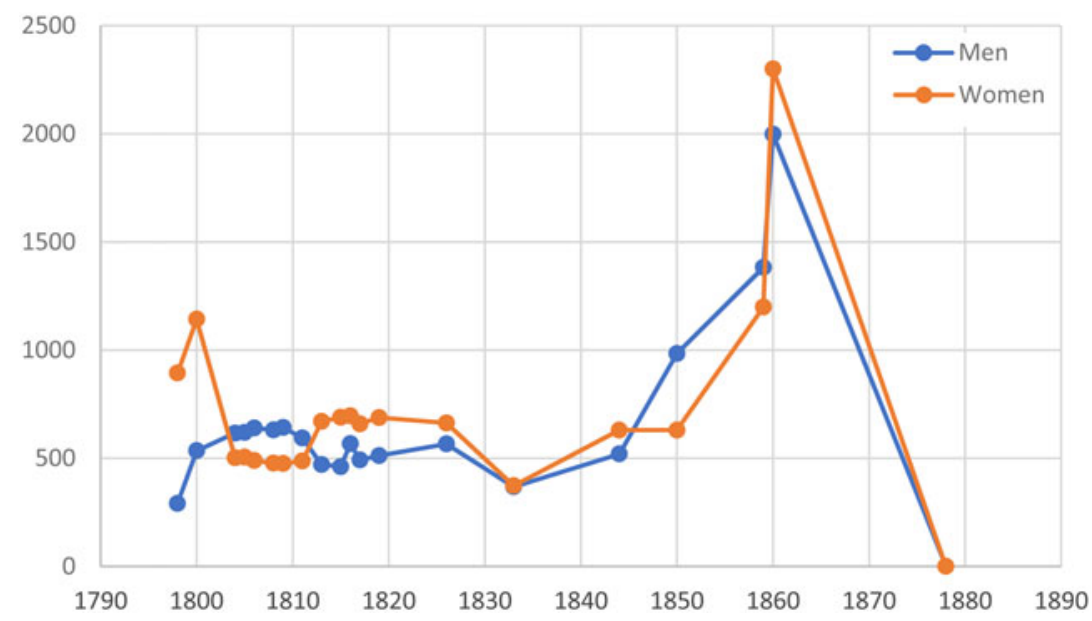

Figure 4. Benguela enslaved population by gender, I $800-1880$.

Sources: AHU, Angola, I section, box 88, document 46; ANA, Codex 442, fols. I6Iv-I62; $A H U$, Angola, I section, box I13, document 6; AHU, Angola, I section, box I I6, document 87; AHU, Angola, I section, box I I , document 2I; AHU, Angola, I section, box I20, document 2I; AHU, Angola, I section, box I2 I, document 32; AHU, Angola, I section, box I24, document 8.; AHU, Angola, I section, box I27, document 59; $A H U$, Angola, I section, box 13 I, document 45; $A H U$, Angola, I section, box 133, document 32; AHU, Angola, I section, box 136, document I9; $A H U$, Angola, I section, box 138, document I; AHU, Angola, I section, box I56, document I6; AHU, Angola, I section, box I76, document I7.

the agricultural economy to export its crops to growing industrialized countries in Europe and North America.

\section{RESISTANCE}

Slavery was not mild in West Central Africa, and evidence suggests its violent nature. Severe physical punishment or the threat of being sent to the Americas may have prevented some slave resistance and uprisings, yet they did occur. ${ }^{76}$ The same violence that generated slaves and maintained control over them

76. On slave resistance and flight in Angola, see Clarence-Smith, "Runaway Slaves"; Freudenthal, "Os quilombos de Angola"; Beatrix Heintze, Asilo ameaçado. Oportunidades e consequências da fuga de escravos em Angola no século XVII (Luanda, I995); Roquinaldo Ferreira, "Escravidão e revoltas de escravos em Angola (1830-1860)", Afro-Ásia, 2 I-22 (1998), pp. 9-44; Roquinaldo Ferreira, "Slave Flights and Runaway Communities in Angola (17th-19th Centuries)", Anos 90, 21:40 (2014), pp. 65-90; Roquinaldo Ferreira, "Slavery and the Social and Cultural Landscape of Luanda", in Jorge Cañizares-Esguerra, Matt Childs, and James Sidbury (eds), The Black Urban Atlantic in the Age of the Slave Trade (Philadelphia, PA, 2013), pp. I85-205. 
could also trigger resistance. ${ }^{77}$ The historical registers did not record acts of daily resistance such as working at a slow pace, sabotaging tasks, or breaking tools; the authorities only recorded instances of violent resistance that demonstrated a physical clash with the system.

Events taking place in the Atlantic world and in the interior of Benguela shaped the ways captives viewed their slavery, inclining them to resist, negotiate, or integrate into the host society. Continuous warfare or political turbulence in the interior as well as social insecurity may have led enslaved individuals to negotiate their labor conditions. Moments of change in the Atlantic world or instability after the death of slave masters encouraged many to run away, as scholars have pointed out. ${ }^{78}$ The authorities feared assembled groups of enslaved individuals, perceived as especially dangerous to social stability particularly in a port town with a large enslaved population. When groups of captives confronted each other in the streets, slaveholders and military personnel feared the consequences. In 18 I 4 , a group of enslaved men who belonged to Justiniano José dos Regos, a Benguela trader, physically attacked the captives of two other merchants, António Lopes Araújo and Francisco Ferreira Gomes. Colonial soldiers had to intervene to control the street fight and were wounded. ${ }^{79}$ These street fights posed a serious threat to Benguela's colonial administration. In the mid-eighteenth century, any enslaved person caught using a knife against a free person could be punished with ios lashes plus two months of forced labor at the disposal of the colonial state. On the second infraction the enslaved person faced double punishment, and after the third time he or she could be deported to Brazil. However, by the early nineteenth century, the authorities had changed this last punishment since it would affect the slave owner, who could lose his property overnight. Authorities instead imposed a new penalty: fifty lashes in a public space. ${ }^{80}$

Running away was an effective way to resist slavery. Colonial records suggest enslaved individuals often escaped and moved inland by following the paths of long-distance trade routes, which may have led them back to their homeland or to inland markets to look for help or follow a trail. In I808, a team led by António headed toward the slave market in Caconda, more than 250 kilometers inland of Benguela, in search of captives who had fled their slaveowners in Benguela. Rumors spread in Benguela that some of António's enslaved females had urged other urban slaves to run away.

77. João José Reis and Eduardo Silva, Negociação e Conflito. A resistência Negra no Brasil Escravista (São Paulo, 1999), pp. I 3-20; Heintze, Asilo ameaçado.

78. Freudenthal, "Os quilombos de Angola"; Clarence-Smith, "Runaway Slaves”, pp. 23-33.

79. AHU, Angola, box I46, doc. I3, 9 November I8I4. On Ferreira Gomes family, see Roquinaldo Ferreira, "Biografia como história social. O clã Ferreira Gomes e os mundos da escravização no Atlântico Sul”, Varia Historia, 29:5 I (2013), pp. 679-719.

80. See AHU, Angola, box 36, doc. 8, 27 March I748; AHU, Angola, box IoI, doc. 38, 25 August I $80 \mathrm{I}$. 
Feeling responsible, António led a team of armed guards, but it is not clear if they ever located the runaway group. ${ }^{81}$

Free people offering help to runaway slaves could be arrested, as happened with dona Ana José Aranha, a black female trader who moved goods and people between inland markets and Benguela in the first decades of the nineteenth century. A resident in the market of Caconda, dona Aranha was one of the largest slave owners and food producers in the inland fortress. In her compound dona Aranha controlled 266 people, including eighty-four enslaved people who cultivated beans and manioc in her fields. Part of her production was probably destined to supply the Benguela population's demand for food. On one of her journeys to Benguela, another trader reported seeing some Benguela runaway captives employed in dona Aranha's caravan. The governor of Benguela ordered her arrest, alleging she was offering protection to runaway slaves and colonial soldiers who had abandoned their positions. ${ }^{82}$ Four decades later, offering asylum to runaway slaves was punished not with arrest but with a fine. In I 846, Rita, a free black woman and resident of Benguela, received a fine of 100,000 reis for hiding two runaway captives. Two runaway women found refuge in Rita's compound after escaping their master's establishment in Benguela. Rita lived close by, and it is not clear if she participated in the escape. Since she had offered asylum and was caught, she was required to pay the fine imposed by the governor. ${ }^{83}$

Although some people were successful in fleeing captivity, the fear of being recaptured was real. This may explain why some individuals would return to Benguela and buy their manumission even after years spent living as a free person. This was the case with José Eleutério, who belonged to the Santa Casa da Misericórdia, the Holy House of Mercy, a Catholic lay institution intimately linked with Portuguese colonialism that operated a hospital in Benguela. When José Eleutério ran away the administrator of the hospital agreed to free him in exchange for 300,000 reis. Over three years later, Eleutério returned to Benguela, paid his manumission, and received his freedom letter in August I 8 I $7 .{ }^{84}$ Cases in the Tribunal da Comarca de Benguela, the courthouse of Benguela, reveal that slave masters resisted freeing their captives even if they managed to save the money to buy their freedom. ${ }^{85}$ Unlike Eleuterio,

8I. ANA, Codex 443, fol. i7 I, 25 January i 808.

82. On D. Aranha's case and her arrest see ANA, Codex 443, fol. Io9v-1 io, is June I 802 . For more on her, see Candido, An African Slaving Port, pp. 169-270.

83. ANA, Codex 444, fol. I 16, 9 October I 846; ANA, Codex 455, fol. 238v, I4 October I 846; ANA, Codex 460 , fol. i iv, 5 October i 846.

84. ANA, Codex I55, fol. Iv, 30 April I817; ANA, Codex I55, fol. 5, 28 August I817.

85 . See, for example, TCB, "Autos crimes de reclamação de liberdade. Ministério Público vs António Martins Bastos, I850", "Reinvindicação de liberdade. Teresa vs Joana Mendes de Moraes, I 860", and "Reinvindicação de liberdade. Júlia vs Josefa Manuel Pereira, I 860", among others. On masters' reluctance to free people, see José C. Curto, “'As If from a Free Womb”: Baptismal Manumissions in the Conceição Parish, Luanda, I778-1807”, Portuguese Studies 
Dorotéia, a runaway enslaved woman, was not able to buy her manumission after escaping her master. She served in the house of Lieutenant José Rodriguez Guimarães for many years until I 837, when she finally found an opportunity to flee. It appears she was able to escape north to the port of Novo Redondo, where she lived as a free trader. However, nine years later in 1846 a colonial officer identified her and informed Guimarães of her location. ${ }^{86}$ It is unclear whether Dorotéia was recaptured. This case clearly reveals that colonial officers kept track of runaway individuals and searched for them even years after their flight.

The fear of runaway captives was constant in Benguela, in part because African rulers could easily offer refuge. The records suggest that running away was a successful strategy for most of the nineteenth century. ${ }^{87}$ Only on very few occasions were colonial forces successful in locating and recapturing runaway individuals. ${ }^{88}$ Under African rulers' jurisdiction, unfree people found mechanisms to escape, even committing crimes to be re-enslaved by someone else who became their new master. Cases like these, known as tumbikar, are rare in the Portuguese documentation since such events occurred beyond the Portuguese scope, but some itinerant merchants reported encountering cases of enslaved people willing to change masters. These cases are only attested for the period after the 1850 s when these accounts were recorded. ${ }^{89}$

The existence of maroon communities in areas surrounding Benguela demonstrates that successful escapes were more common than the colonial sources indicate..$^{90}$ Anyone who offered asylum to runaway slaves could face severe retaliation. In the I 840 s and I 850 s, authorities and slave owners sometimes accused free or freed blacks of helping runaway slaves with promises of better and safer lives. The Benguela trader António Joaquim Monteiro accused Matias, also known as Matias do sertão, of convincing Monteiro's captives to run away in I 848 . Sixteen of Monteiro's enslaved individuals planned to escape to the interior, but only three succeeded. With the collaboration of colonial

Review, I0:I (2002), pp. 26-57; Oliveira, "Slavery and the Forgotten Women Slave Owners of Luanda".

86. ANA, Codex I66, fol. I 34v, i7 July i 846.

87. ANA, Codex 443, fol. I 56, 27 October I 807; ANA, Codex 509, fol. $256 \mathrm{v}-257,7$ December I 837; AHU, Angola, Correspondência dos Governadores, Folder 5 B, 24 December I 842; ANA, Codex 456, fol. I08v, 3 I October I844; ANA, Codex 46r, fol. 33, 4 June i 847; ANA, Codex 463, fol. I I 4 v, 3 I May i 848 .

88. BOGGPA, no. 5 I 3 , 28 July I 855 .

89. Magyar, Reisen in Süd-Afrika, ch. 7: “A Nação dos Quimbundos e seus Costumes”, p. I9; Heintze, Asilo ameaçado.

90. Portuguese agents used the term quilombo to refer to maroon communities during the nineteenth century; see ANA, Codex 455, fol. 25 I-25IV, 2 November I 846. For a discussion of the term, see Freudenthal, "Os quilombos de Angola”, pp. I09-I34; Maria Conceição Neto, "Kilombo, Quilombos, Ocilombo", Revista Mensagem (Luanda), 4 (1989), pp. 5-19. For more on quilombos in Benguela see Ralph Delgado, Ao Sul do Cuanza (ocupação e aproveitamento do Antigo Reino de Benguela) (Lisbon, 1944), pp. 2, 623. 
forces, Monteiro later apprehended all of them, including one in Matias's company. All of them quickly blamed Matias for their actions. ${ }^{9 \mathrm{I}}$ Free black people helped runaway slaves, usually leading them toward the interior in search of the protection of African rulers. Zambo, a free black man from the Dombe region, helped an enslaved woman belonging to dona Margarida to escape. In 1847 , Portuguese agents pursued and captured both in the interior. ${ }^{92}$ Occasionally, African rulers returned the runaway individuals to the Portuguese authorities, as in the case of the soba Marango from Ganda who recaptured a portion of the 130 runaway captives who had escaped from Marques Esteves, a resident of Catumbela. For his cooperation, the soba received ten firearms, gunpowder, textiles, and alcohol. However, soba Marango also wanted a cash reward beyond the goods he received..$^{93}$ One can only imagine the punishment that recaptured runaway enslaved individuals endured, since the historical documents provide little information.

Running away was relatively easy and offered a greater chance of success than more aggressive alternatives such as violent attacks against slave owners or uprisings. It also offered quicker access to freedom than negotiating access to manumission. The colonial records are limited and problematic and provide few clues about daily resistance. For example, unlike the case of Luanda, no information has been located on runaway slave announcements. ${ }^{94}$ The number of escaped captives who were never recaptured is unknown. The sources are also limited to enslaved individuals under Portuguese jurisdiction, so little information is available on the nature of resistance of enslaved individuals who lived under the jurisdiction of African rulers.

\section{CONCLUSION}

The nineteenth century can only be considered the age of emancipation if we ignore the fact that the slave trade expanded after I $80 \mathrm{I}$ in the South Atlantic world. Unlike other places in the Atlantic world, in Benguela the nineteenth century was not a moment of freedom but a period when slavery expanded dramatically. Although slave exports were prohibited in 1836 , the trade in human beings continued until the i 860 s. In fact, the use of slave labor expanded after I 836 and the number of enslaved people in Benguela increased. In the colonial center enslaved people performed most of the work, both public and private. In the wake of the end of the slave trade, so-called legitimate trade expanded. Ironically, the legitimate commerce relied on forced labor to

91. ANA, Codex 46I, fol. 7I-72, 5 June I848; ANA, Codex 462, fol. I०8-I I0, 9 June I 848.

92. ANA, Codex 463, fol. 27,27 November 1847 .

93. Delgado, Ao Sul do Cuanza, pp. I, 544-545.

94. José C. Curto, "Resistência à escravidão na África. O caso dos escravos fugitivos recapturados em Angola, i 846-1876”, Afro-Ásia, 33 (2005), pp. I-2 I. 
supply the growing demand in Europe and North America for cotton, sugar, and natural resources such as wax, ivory, rubber, and gum copal. Thus, any attempt to portray the nineteenth century as an age of freedom and liberty excludes not only West Central Africa, but also events in other parts of the Atlantic world such as Brazil or Cuba.

In Portuguese territories in West Central Africa, slavery remained alive until I869, when enslaved people were put into systems of apprenticeship very similar to labor regimes elsewhere in the Atlantic world. For the thousands of people who remained in captivity in Benguela, the nineteenth century continued to be a time of oppression, forced labor, and extreme violence. Yet, enslaved individuals resisted through flight and small acts of resistance that sabotaged masters and the colonial economy. Their resistance indicates that slavery in West Central Africa was as violent and oppressive as anywhere else in the Atlantic world. 